\title{
Alergénios Alimentares: o que São, o que Provocam E COMO DETETÁ-LOS?
}

\author{
Joana Costa, Maria Beatriz P.P. Oliveira e Isabel Mafra*
}

\begin{abstract}
A
prevalência das alergias alimentares tem vindo a aumentar nos últimos anos, constituindo um problema de saúde pública, com expressão mais relevante nas sociedades ocidentais. Atualmente estima-se que cerca de 2 a $4 \%$ da população adulta e 6 a $8 \%$ da população jovem possa padecer de algum tipo de alergia alimentar. A inexistência de terapêuticas efetivas para este tipo de patologia tem levado a uma crescente preocupação da população alérgica quanto aos alimentos disponiveis no mercado, dado que a única forma de se protegerem contra possíveis reações alérgicas consiste na eliminação dos alimentos alergénicos da sua dieta. A proteção destes indivíduos é apenas assegurada pela legislação que obriga a rotulagem de todos os ingredientes considerados potencialmente alergénicos nos alimentos pré-embalados. Para a verificação do cumprimento da rotulagem, é de extrema importância o desenvolvimento de metodologias analíticas adequadas para a sua monitorização. Dada a crescente necessidade de métodos analíticos com elevados níveis de sensibilidade e seletividade para a deteção e quantificação dos alergénios alimentares, têm sido propostas várias técnicas com base nas proteínas ou no ADN. No entanto, deverá ainda ser desenvolvido muito trabalho para que se possa responder à necessidade de estabelecer metodologias oficiais e materiais de referência adequados para a gestão de alergénios em alimentos.
\end{abstract}

\section{AleRgias ALIMENTARES: O QUE SÃO?}

Nos últimos anos, as alergias alimentares têm sido consideradas um problema emergente de saúde pública, com especial ênfase nas sociedades ocidentais. Estas definem-se como reações adversas do sistema imunitário em indivíduos sensibilizados à presença de proteínas (geralmente glicoproteínas) que ocorrem naturalmente nos alimentos.

As alergias alimentares podem ser divididas em duas categorias, de acordo com o tipo de resposta imune desencadeado. Um dos grupos corresponde às reações de hipersensibilidade imediata, quando a resposta adversa é mediada pelos anticorpos específicos da imunoglobulina $E$ ( $\operatorname{lgE}$ ) para um dado alergénio. Estas reações devem a sua designação ao facto dos sintomas aparecerem dentro de poucos minutos até algumas horas após a ingestão do alimento alergénico. A segunda categoria corresponde às reações de hipersensibilidade retardada por serem mediadas pelas células $T$ do sistema imunitário, pelo que os sintomas aparecem 24 a 48 horas após o consumo do alimento alergénico [1].

\footnotetext{
*REQUIMTE, Departamento de Ciências Químicas, Faculdade de Farmácia, Universidade do Porto, Porto
} E-mail: isabel.mafra@ff.up.pt

\section{PreVALÊNCIA DAS ALERGIAS ALIMENTARES}

Estudos recentes estimam que a prevalência das alergias alimentares tem vindo a aumentar e que possa afetar cerca de 2 a $4 \%$ da população mundial, atingindo um número superior entre a população jovem (8\% de crianças e adolescentes). Só na Europa avalia-se que o número de pacientes alérgicos possa ascender aos 20 milhões de indivíduos. As alergias alimentares podem ser induzidas por uma grande variedade de alimentos, no entanto, cerca de $90 \%$ das reações alérgicas são atribuídas a classes res- tritas de alimentos. Estes estão reunidos em oito grupos e são vulgarmente conhecidos como the big-8 (Figura 1): ovos, leite, soja, trigo (glúten), crustáceos (marisco), peixe, amendoim e frutos de casca rija (amêndoa, noz, avelã, noz-pecã, noz de macadâmia, pistácios, caju e noz do Brasil). Embora qualquer um destes alimentos possa desencadear reações alérgicas, alguns deles, nomeadamente os amendoins e os frutos de casca rija, estão entre aqueles que podem causar reações adversas graves ou mesmo fatais. Atualmente, as alergias induzidas pela ingestão de frutos de casca rija são a principal causa

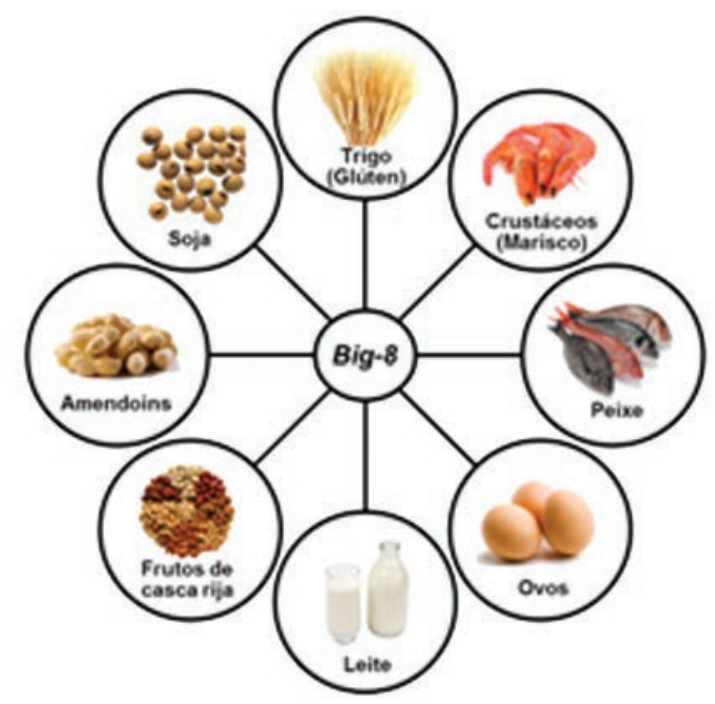

Figura 1 - Representação dos 8 grupos de alimentos (big-8) responsáveis por desencadear cerca de $90 \%$ das reações alérgicas 
de anafilaxia, levando todos os anos um elevado número de indivíduos em todo o mundo a recorrer às urgências dos hospitais. A anafilaxia desencadeada pelo consumo de alimentos pode ocorrer em indivíduos de qualquer idade e como consequência da ingestão de qualquer alimento. Contudo, as fatalidades provocadas por choques anafiláticos têm maior incidência entre os adolescentes e os jovens adultos, sendo frequentemente relacionadas com consumo de amendoins e frutos de casca rija (avelã, amêndoa e noz). Pacientes com diagnóstico duplo de alergias mediadas pela IgE associadas à asma e a alimentos revelam um risco acrescido de episódios de anafilaxia despoletados pela ingestão destes alimentos. Nestes casos, o atraso na administração de injeção de epinefrina como medida retificativa a uma exposição acidental ao ingrediente alergénico resulta, geralmente, em fatalidade [2].

A quantidade exata de um alergénio capaz de induzir uma resposta alérgica depende de vários fatores, ou seja, varia de indivíduo para indivíduo, da altura do dia, da existência de infeções, da prática de exercício físico e/ ou de situações de stress. Os indivíduos alérgicos podem ainda apresentar diferentes graus de sensibilidade a um alimento alergénico específico, pelo que as quantidades mínimas capazes de incitar uma resposta alérgica ainda estão por definir. No entanto, estudos revelam que quantidades tão baixas quanto $1 \mathrm{mg}$ de alergénio podem ser suficientes para induzir uma reação adversa em alguns indivíduos alérgicos [1]. No caso especifico da avelã, as doses de alergénio capazes de despoletar sintomas adversos observáveis em indivíduos sensibilizados podem variar de 1 a $100 \mathrm{mg}$, o que equivale ao consumo de $6,4 \mathrm{a}$ 640 mg de avelã numa refeição.

Os estudos populacionais baseados na prevalência das alergias alimentares são ainda muito escassos, evidenciando a enorme falta de informação acerca deste tópico. Apesar de ser classificado pela Organização Mundial de Saúde (OMS) como o quarto principal problema de saúde pública, ainda não existem tratamentos efetivos para este tipo de patologia. Em consequência, os indivíduos alérgicos são aconselhados a retirar da sua dieta todos os alimentos que possam eventualmente conter os ingredientes alergénicos. Adicionalmente, estes pacientes são ainda aconselhados a evitar alimentos suscetíveis de provocar eventual reatividade cruzada com o ingrediente alergénico, uma vez que a frequência de reações alérgicas desencadeadas por alimentos da mesma família é muito comum. No caso particular de alergia a um fruto de casca rija, como a amêndoa, o paciente é fortemente aconselhado a eliminar da sua dieta o consumo de outros frutos de casca rija e de frutos da mesma família da amêndoa, como as maçãs, as cerejas, os pêssegos, de entre outros [3]. Sabe-se que algumas reações imunológicas adversas a certos alimentos podem ser minimizadas ao longo do tempo. Um exemplo de alergias que podem diminuir de intensidade com o avanço para a idade adulta é o caso da ingestão de leite. No entanto, outras alergias alimentares, como as provocadas pelos frutos de casca rija, são normalmente persistentes e sem tendência a desaparecerem. Apesar de todas as precauções, a total supressão destes produtos da alimentação é muito difícil de manter. Estima-se que cerca de 50\% das crianças com histórico de alergia alimentar mediada pela IgE possa sofrer uma exposição acidental ao alergénio em questão nos primeiros 5 anos após o diagnóstico, subindo este número para os $75 \%$ nos primeiros 10 anos depois do diagnóstico [1].

\section{ENQUADRAMENTO LEGAL}

O alerta para a existência de moléculas naturais presentes nos alimentos e que induziam reações alérgicas num número significativo de indivíduos levou, em 1985, a que a Comissão do Codex Alimentarius publicasse uma lista contendo um conjunto de alimentos considerados responsáveis por induzir hipersensibilidade em indivíduos sensibilizados e aconselhando a rotulagem obrigatória destes. Desde então, tem vindo a ser dedicada uma especial atenção ao estabelecimento de diretivas claras com respeito à rotulagem de alimentos alergénicos, o que levou a União Europeia (UE), pela primeira vez, a incluir os alimen- tos potencialmente alergénicos no anexo IIla da Diretiva 2000/13/EC. De acordo com esta, a indústria alimentar era obrigada a declarar no rótulo todos os ingredientes utilizados na preparação de alimentos pré-embalados sujeitos a comercialização dentro da UE, com muito poucas exceções. Das alterações que têm surgido à referida diretiva, destaca-se a presente lista contendo um total de 14 grupos de alimentos (ovos, leite, soja, trigo (glúten), crustáceos, peixe, amendoim, frutos de casca rija, aipo, mostarda, sésamo, tremoço, moluscos e sulfitos) suscetíveis de induzir reações alérgicas em indivíduos sensibilizados, com a obrigatoriedade da sua rotulagem, independentemente da sua quantidade (Diretiva 2007/68/CE). A rotulagem correta dos alimentos pré-embalados constitui uma das formas mais efetivas para a proteção dos indivíduos alérgicos, visando essencialmente possibilitar uma escolha informada acerca dos produtos que adquirem. No entanto, de forma a obedecer à diretiva vigente da UE e a proteger-se de possíveis processos, a indústria alimentar tem feito um uso excessivo da rotulagem de precaução com a alegação "pode conter vestígios de...", o que condiciona a escolha dos produtos alimentares a consumir e a qualidade de vida dos indivíduos sensibilizados/alérgicos. Como exemplo, para um paciente alérgico à avelã, a escolha de um simples chocolate de leite pode ser tarefa impossível, dado que praticamente todos os chocolates possuem no seu rótulo a declaração "pode conter vestígios de frutos de casca rija". Sem limites legais estabelecidos que restrinjam a rotulagem de precaução, os pacientes não têm outra alternativa, a não ser evitar na totalidade o consumo dos referidos alimentos.

\section{O QUE SÃO ALERGÉNIOS ALIMENTARES?}

Os alergénios são antigénios com capacidade de desencadear uma resposta imunitária adversa em indivíduos sensibilizados. Bioquimicamente, os alergénios são maioritariamente glicoproteínas, solúveis em água e resistentes à digestão. São reconhecidos pelo sistema imunitário, levando à produção de anticorpos específicos do tipo IgE. Normalmente apresentam 
pesos moleculares que podem variar entre os 3-160 kDa, mas os alergénios mais comuns tem pesos moleculares entre 20 a 40 kDa. Muitas destas moléculas evidenciam atividade enzimática, o que lhes faculta a capacidade de atravessar a barreira da membrana mucosa. Na superfície tridimensional destas proteínas existem os chamados epítopos, que permitem a ligação destas moléculas aos centros ativos da IgE (Figura 2). No caso de existir uma sensibilização prévia a um dado alergénio, o sistema imunitário desenvolve anticorpos específicos para as moléculas alvo. Contudo, qualquer molécula que apresente epítopos semelhantes pode ser responsável por desencadear reações adversas do mesmo tipo (reatividade cruzada). A resposta alérgica inicia-se com a ativação dos mastócitos, levando à libertação de histamina, citocinas, prostaglandinas, entre outras. Este processo desencadeia o aparecimento dos sintomas cuja intensidade varia em função do grau de exposição ao alergénio em questão.

As proteínas que induzem respostas imunitárias adversas pertencem a diferentes grupos ou famílias (Tabela 1).

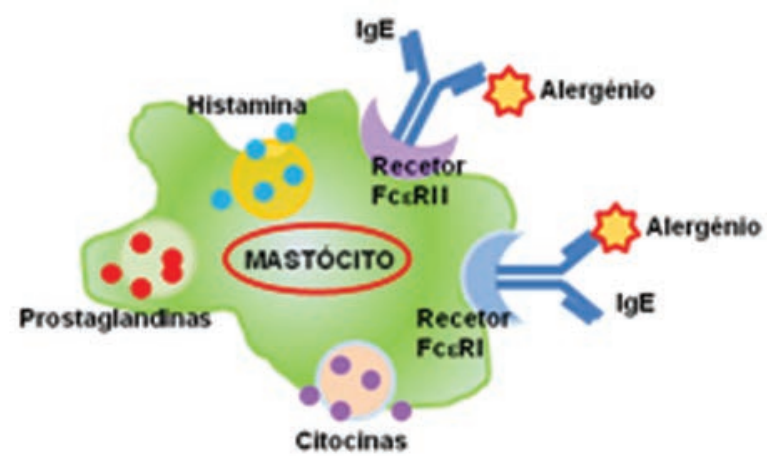

Figura 2 - Representação da resposta alérgica desencadeada pela presença de alergénio alimentar. Ligação do alergénio às IgE, que leva à desgranulação dos mastócitos e consequente libertação de histamina, citocinas e prostoglandinas

No caso dos alergénios de origem animal, estes são essencialmente proteínas de transporte (albuminas, globulinas e caseínas) ou de regulação/estrutural (tropomiosinas e parvalbuminas). Os alergénios de origem vegetal são na sua grande maioria proteínas de reserva como as vicilinas, $2 \mathrm{~S}$ albuminas e leguminas, mas também existem vários que desempenham funções de transporte (Lipid Transfer Proteins - LTP), estruturais (profilinas) e de defesa (Pathogen-Related Protein - PR-10).

\section{MOLÉCULAS ALVO: PROTEÍNAS} OU ADN?

O desenvolvimento de metodologias analíticas que possam verificar a veracidade da rotulagem e, mais importante, ajudar a indústria alimentar a controlar a presença de ingredientes potencialmente alergénicos, como forma de prevenir a ocorrência de contaminações cruzadas, é de extrema importância [3]. Presentemente, apesar de existirem vários métodos analíticos disponíveis na literatura visando a deteção e quantificação de alergénios alimentares, nenhum deles é ainda

Tabela 1 - Representação das oito classes de alimentos potencialmente alergénicos com a respetiva classificação das proteínas, função bioquímica de cada grupo e exemplos de alergénios conhecidos

\begin{tabular}{|c|c|c|c|}
\hline Classe de alimentos & Classes de proteínas & Função bioquímica & Exemplo de alergénios \\
\hline Ovos & Albuminas & Transporte & Gal d 2 \\
\hline Peixe & Parvalbuminas & Regulação & $\begin{array}{l}\text { Gad c } 1 \text { (bacalhau do atlântico, comum à maioria } \\
\text { dos peixes) }\end{array}$ \\
\hline Leite & $\begin{array}{l}\text { Globulinas } \\
\text { Caseínas } \\
\text { Albuminas }\end{array}$ & \begin{tabular}{|l} 
Transporte \\
Transporte \\
Transporte/regulação
\end{tabular} & $\begin{array}{l}\text { Bos d } 8 \\
\text { Bos d } 4 \\
\text { Bos d } 5\end{array}$ \\
\hline Crustáceos & Tropomiosinas & Regulação/estrutural & $\begin{array}{l}\text { Pen i } 1 \text { (camarão) } \\
\text { Cha f } 1 \text { (caranguejo) }\end{array}$ \\
\hline Soja & $\begin{array}{l}\text { Leguminas } \\
\text { Vicilinas } \\
\text { Profilinas } \\
\text { PR-10 }\end{array}$ & $\begin{array}{l}\text { Reserva } \\
\text { Reserva } \\
\text { Estrutural } \\
\text { Defesa }\end{array}$ & $\begin{array}{l}\text { Gly } m 6 \\
\text { Gly } m 5 \\
\text { Gly } m 3 \\
\text { Gly } m 4\end{array}$ \\
\hline $\begin{array}{l}\text { Frutos de casca rija (amêndoa, noz, } \\
\text { avelã, caju, pistácio, noz pécan, noz de } \\
\text { macadâmia e noz do Brasil) }\end{array}$ & $\begin{array}{l}\text { PR-10 } \\
\text { LTP } \\
\text { Profilinas } \\
\text { Vicilinas } \\
\text { Leguminas } \\
\text { 2S albuminas }\end{array}$ & \begin{tabular}{|l|} 
Defesa \\
Transporte \\
Estrutural \\
Reserva \\
Reserva \\
Reserva
\end{tabular} & $\begin{array}{l}\text { Cor a } 1 \text { (avelã), Pru du } 1 \text { (amêndoa) } \\
\text { Pru du } 3 \text { (amêndoa), Cor a } 8 \text { (avelã) } \\
\text { Pru du } 4 \text { (amêndoa), Jug r } 5 \text { (noz) } \\
\text { Cor a } 11 \text { (avelã), Jug r } 2 \text { (noz) } \\
\text { Car i } 4 \text { (noz pécan), Ana o } 2 \text { (caju) } \\
\text { Pis v } 1 \text { (pistácio), Ber e } 1 \text { (noz do Brasil) }\end{array}$ \\
\hline Amendoins & $\begin{array}{l}\text { Vicilinas } \\
\text { 2S albuminas } \\
\text { Leguminas } \\
\text { Profilinas } \\
\text { Oleosinas } \\
\text { PR-10 } \\
\text { LTP }\end{array}$ & $\begin{array}{l}\text { Reserva } \\
\text { Reserva } \\
\text { Reserva } \\
\text { Estrutural } \\
\text { Estrutural } \\
\text { Defesa } \\
\text { Transporte }\end{array}$ & $\begin{array}{l}\text { Ara h } 1 \\
\text { Ara h 6/Ara h } 7 \\
\text { Ara h } 3 \\
\text { Ara h } 5 \\
\text { Ara h 10/Ara h } 11 \\
\text { Ara h } 8 \\
\text { Ara h } 9\end{array}$ \\
\hline Trigo & $\begin{array}{l}\text { Profilinas } \\
\text { LTP } \\
\text { Tiorredoxinas } \\
\text { Gliadinas } \\
\text { Gluteninas }\end{array}$ & $\begin{array}{l}\text { Estrutural } \\
\text { Transporte } \\
\text { Transporte } \\
\text { Reserva } \\
\text { Reserva }\end{array}$ & $\begin{array}{l}\text { Tri a } 12 \\
\text { Tri a } 14 \\
\text { Tri a } 25 \\
\text { Tri a } 19 / \text { Tri a } 21 \\
\text { Tri a } 26\end{array}$ \\
\hline
\end{tabular}


oficial. Os requisitos necessários para responder às exigências impostas pela legislação envolvem parâmetros de elevada sensibilidade e especificidade para rastrear quantidades vestigiais de alergénios e/ou respetivos marcadores em matrizes complexas, tais como os alimentos processados. Para tal, a definição dos limites superiores permitidos para a presença de componentes alergénicos como não-ingredientes seria um importante progresso para a proteção dos consumidores alérgicos. Contudo, estes limites só têm significado se existirem metodologias disponíveis capazes de verificarem o cumprimento dos mesmos. Atualmente, pensa-se que os limites de deteção dos métodos usados na deteção de alergénios em alimentos deverão rondar os 1-100 mg/kg, o que constitui uma gama de concentrações bastante baixa para a maioria das técnicas disponíveis. Aliada à problemática do desenvolvimento de técnicas específicas e sensíveis para a deteção de ingredientes alergénicos em alimentos, acresce a falta de materiais de referência que permitam a sua otimização e validação [3].

As metodologias mais utilizadas baseiam-se em protocolos imunológicos ou imunoquímicos, como os ensaios ELISA (Enzyme-Linked Immunosorbent Assay), Figura 3, e as tiras de fluxo lateral, cujo mecanismo se fundamenta na deteção direta de proteínas alergénicas/marcadoras, mediante uma reação imunológica anticorpo-proteína. A aplicação de anticorpos poli- ou monoclonais para a deteção de ingredientes alergénicos nos alimentos processados tem sido amplamente explorada com sucesso. No caso específico do amendoim e dos frutos de casca rija (caso da amêndoa, noz, avelã, noz de macadâmia, pistácio e caju), encontram-se disponíveis comercialmente vários kits de tiras de fluxo lateral e de testes ELISA que permitem a deteção/quantificação dos alergénios alvo. Estes kits indicam a possibilidade de detetar e quantificar o ingrediente alergénico até um limite de $2,5 \mathrm{mg} / \mathrm{kg}$, revelando elevada sensibilidade. Este tipo de testes é o mais usado pela indústria alimentar, uma vez que é de fácil execução e não requer equipamento específico. Alternativamente aos testes ELISA, surgiram os biossensores, que são considerados métodos imunológicos muito atrativos por permitirem a deteção múltipla de diferentes alergénios em alimentos, baseando o seu funcionamento na interação anticorpo-proteína. Têm revelado uma vasta aplicação nesta área, nomeadamente na identificação de avelã e amendoim, com limites de deteção comparáveis aos ensaios ELISA mais sensíveis (1-10 $\mathrm{mg} / \mathrm{kg})$. No entanto, a elevada suscetibilidade dos ensaios imunoquímicos à reatividade cruzada com proteínas não alvo, tornam a sua fiabilidade limitada. Acresce ainda o facto dos referidos ensaios terem como alvo a deteção direta de proteínas, que são moléculas com baixa resistência a variações de $\mathrm{pH}$ e/ou temperatura, condições essas que são frequentemente utilizadas durante o processamento dos alimentos. Como consequência, as estruturas das proteínas podem sofrer alterações conformacionais (desnaturação), o que pode invalidar a sua deteção. Deste modo, embora os ensaios imunológicos sejam ferramentas valiosas na avaliação de alimentos crus ou pouco processados, a sua aplicação em produtos processados deverá ser criteriosa.

Ainda com base na deteção direta das proteínas alergénicas/marcadoras, mas visando a eliminação da utilização de anticorpos e os problemas associados às alterações tridimensio- nais das proteínas, surgiu nos últimos anos a abordagem por espetrometria de massa (MS) acoplada com análise bioinformática. Estas técnicas permitem efetuar, em simultâneo, a deteção, a quantificação e a identificação de péptidos alergénicos e/ou péptidos marcadores da espécie alvo. A aplicação da análise por espetrometria de massa acoplada a técnicas de cromatografia liquida com ionização por electrospray com a capacidade da deteção de múltiplos péptidos-alvo numa única corrida, torna esta metodologia numa estratégia muito promissora para a análise de alergénios alimentares. Trabalhos recentes revelam o sucesso na aplicação da análise por MS para o rastreio de frutos de casca rija em alimentos com limites de deteção de $3 \mathrm{mg} / \mathrm{kg}$. Porém, o elevado custo do equipamento e da sua manutenção, e a exigência de pessoal com elevado grau de especialização para manter a plataforma MS, condiciona o amplo desenvolvimento e aplicação destes métodos em análises de rotina [3].

Como metodologias alternativas à deteção direta das moléculas alergénicas (proteínas), surgiram as técnicas de análise indireta baseadas no ADN. Durante a sua preparação, os alimentos processados são comummente sujeitos a tratamentos térmicos, o que pode levar à desnaturação das proteínas presentes, tornando-as "invisíveis" para os métodos imunológicos utilizados na sua deteção. Ainda que muitas destas moléculas percam a atividade alergénica, a sua desnaturação pode também levar ao aparecimento de novos epítopos capazes de desencadear respostas imunitárias anormais, representando um potencial risco para os indivíduos alérgicos. As moléculas de ADN evidenciam maior estabilidade do que as proteí-
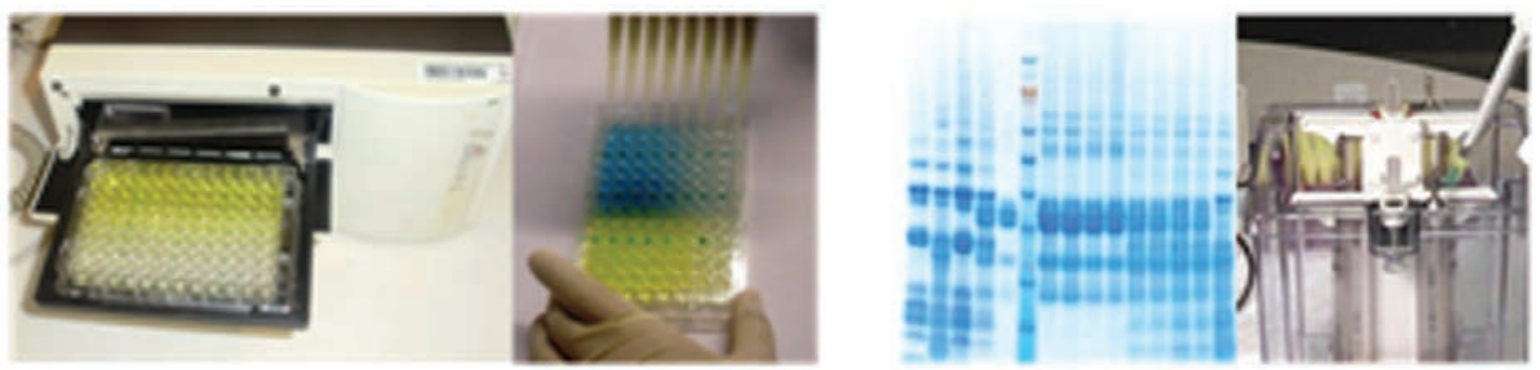

Figura 3 - Sistemas ELISA usados na deteção e quantificação de ingredientes alergénicos em alimentos processados 
nas, além de estarem disponíveis na maioria dos tecidos biológicos, o que as transforma em alvos preferenciais para a diferenciação e identificação de alergénios ou ingredientes alergénicos em alimentos com elevado grau de processamento [3, 4]. As técnicas baseadas na deteção do ADN consistem na amplificação de uma região alvo que codifica a proteína alergénica ou de um gene marcador de espécie com recurso à reação em cadeia da polimerase (PCR). Na PCR, as cadeias duplas do ADN são separadas por desnaturação a elevada temperatura $\left(94-96^{\circ} \mathrm{C}\right)$, seguindo-se a hibridação dos primers que se ligam aos locais complementares de cada uma das cadeias alvo $\left(50-65^{\circ} \mathrm{C}\right)$ e respetiva amplificação por ação de uma polimerase termorresistente a $72^{\circ} \mathrm{C}$, obtendo-se no final de 30 ciclos de amplificação mais de $10^{9}$ fragmentos de ADN. A especificidade e seletividade do método baseiam-se na escolha das sequências dos oligonucleótidos designados por primers com complementaridade para a região do ADN alvo e nas condições de hibridação dos mesmos. A elevada sensibilidade e especificidade associadas à relativa simplicidade e rapidez tornam a técnica de PCR adequada para análises de rotina e também como ferramenta de confirmação. Apesar das vantagens óbvias dos métodos de ADN, o facto de ser uma abordagem indireta, isto é, não baseada na deteção de moléculas capazes de desencadearem as reações adversas, fazem com que sejam contestados por vários autores.

No entanto, o mesmo acontece com a maioria dos testes ELISA, uma vez que estes frequentemente não detetam as proteínas alergénicas, mas sim proteínas marcadoras da espécie. Não obstante a divergência de opiniões, as técnicas baseadas na PCR têm vindo a ser extensivamente utilizadas na deteção e quantificação de alergénios em alimentos processados. Neste sentido, as técnicas de PCR qualitativa ou convencional e de PCR em tempo real têm sido largamente aplicadas na deteção de alergénios nos alimentos, sendo a última adequada à quantificação. No caso específico da identificação e quantificação de frutos de casca rija como ingredientes potencialmente alergé- nicos, existem alguns kits disponíveis comercialmente para a amêndoa, a avelã, a noz, o caju, o pistácio e o amendoim. Os referidos kits permitem atingir limites de deteção relativos e absolutos de 0,4 a 4 mg/kg e 5 cópias de ADN do respetivo ingrediente alergénico. No entanto, nenhum deles disponibiliza qualquer informação sobre a performance de ensaios de reatividade com outras espécies vegetais, nomeadamente com outros frutos de casca rija.

A literatura também disponibiliza um conjunto de metodologias baseadas no ADN para a deteção de frutos de casca rija em alimentos. Com limites de deteção ligeiramente superiores aos registados pelos métodos imunológicos, as técnicas de PCR em tempo real revelam maior especificidade e seletividade com menores ocorrências de reatividades cruzadas. Neste contexto, e visando a obtenção de limites de deteção e quantificação mais baixos, têm vindo a ser desenvolvidos alguns trabalhos com recurso à PCR em tempo real. Esta técnica permite a monitorização da produção do ADN alvo ao longo da amplificação através da aquisição de sinal de fluorescência por adição de corantes específicos ou sondas marcadas para o efeito. Para além da sensibilidade e especificidade acrescidas, comparativamente à PCR convencional, a vantagem adicional da quantificação é uma mais-valia na análise de alimentos.

Neste sentido, para a deteção de alergénios da amêndoa foi muito recentemente desenvolvido um método de PCR em tempo real com análise por high resolution melting (HRM) [5]. A análise por HRM emergiu dos avan- ços recentes nos equipamentos de elevada resolução e do aparecimento de corantes mais especializados para intercalar as cadeias duplas dos ácidos nucleicos (ex. EvaGreen).

Esta abordagem tem sido largamente utilizada nas áreas da saúde, nomeadamente para a genotipagem, estudos de despistagem de mutações genéticas, descodificação do ADN e edição de ARN, dado que permite distinguir pequenas alterações (substituições/deleções/inserções nucleotídicas) em fragmentos de PCR com tamanho e composição semelhantes. Atendendo às inúmeras potencialidades e vantagens da análise por HRM, a sua aplicação foi proposta com sucesso na identificação de alergénios da amêndoa em alimentos processados, tendo atingido um limite de deteção relativo de $50 \mathrm{mg} / \mathrm{kg}$. A análise por HRM permitiu também diferenciar a amêndoa de outros frutos do género Prunus (pêssego e alperce) [5], o que atesta a sua aplicabilidade para a identificação e diferenciação de espécies. Ainda visando o aperfeiçoamento de métodos moleculares de elevada especificidade e sensibilidade, foi desenvolvida outra nova estratégia combinando as vantagens de duas técnicas moleculares, nomeadamente a PCR nested e a PCR em tempo real, num novo sistema designado por single-tube nested real-time PCR. A nova técnica foi aplicada para a deteção e quantificação relativa de alergénios da amêndoa e da avelã revelando uma elevada performance em ambos os sistemas (Figura 4) [6, 7]. Permitiu baixar o limite de deteção e quantificação relativo da avelã e da amêndoa para $50 \mathrm{mg} / \mathrm{kg}$, sendo este limite duas vezes inferior ao obtido com os res-

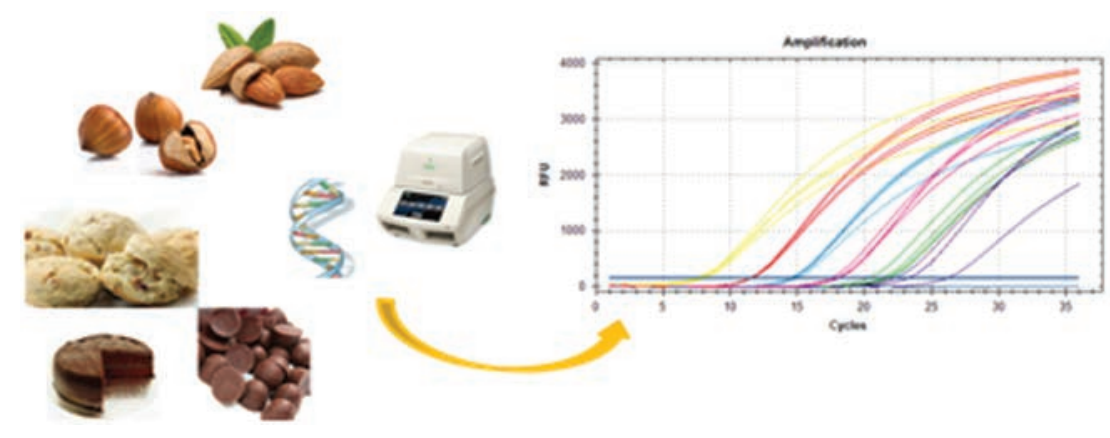

Figura 4 - Sistemas baseados na PCR em tempo real para a deteção e quantificação de alergénios de frutos de casca rija em alimentos processados 
petivos sistemas convencionais de PCR em tempo real. Em termos absolutos possibilitou a amplificação até 0,5 pg de avelã, o que corresponde a uma cópia de $A D N$, sendo este valor o mais baixo reportado na literatura [6]. No caso da amêndoa, o novo sistema permitiu a deteção absoluta de aproximadamente 4 cópias de ADN $(1,28$ $\mathrm{pg}$ ), sendo de igual forma o valor mais baixo atingido [7].

Este sistema revelou elevada versatilidade, dado que apresenta performances melhoradas, independentemente da matriz alimentar e do respetivo alvo, quando comparado com os sistemas convencionais de PCR em tempo real. Esta metodologia de single-tube nested real-time PCR provou ainda ser uma ferramenta alternativa com elevado potencial para a deteção e quantificação de diversos alergénios alimentares, tanto em matrizes cruas como em matrizes sujeitas a elevado grau de processamento.

\section{CONSIDERAÇÕES FINAIS}

Em suma, apesar dos inúmeros avanços, há ainda muito a desenvolver relativamente à temática da deteção e quantificação de alergénios em alimentos. As opiniões continuam a divergir e a constituírem fonte de debate acerca da melhor metodologia para a avaliação da presença/ausência de ingredientes potencialmente alergénicos em alimentos processados. Até à data, nenhuma das metodologias apresentadas, tanto baseadas na deteção direta de proteínas alergénicas, como, de forma indireta, através do ADN, satisfaz plenamente todos os requisitos considerados adequados para a deteção de alergénios em alimentos processados.

A inexistência de valores máximos legislados para a presença de ingredientes alérgicos em alimentos e de métodos oficiais para a sua deteção e quantificação continuam a constituir obstáculos para a melhor gestão deste problema de saúde pública. Num futuro próximo espera-se que estes requisitos de prevenção encontrem resposta, permitindo ir ao encontro das necessidades da indústria alimentar, de forma a facilitar a gestão de ingredientes alergénicos e a obter rotulagem mais efetiva e segura, num contexto de maior liberdade de escoIha dos indivíduos alérgicos.

\section{AgRAdECIMENTOS}

Este trabalho teve o apoio da FCT, através do financiamento PEst-C/ EQB/LA0006/2011 e do projeto de Co- operação Transnacional e Tecnológica FCT/Eslováquia FCT/2489/3/6/2011/S, e da Universidade do Porto, através de "Projectos Pluridisciplinares" IJUP2011-176. Joana Costa agradece à FCT a bolsa de doutoramento (SFRH/BD/64523/2009) financiada pelo POPH-QREN (subsidiado pelo FSE e MCTES).

\section{REFERÊNCIAS}

[1] L.M.L. Nollet and A.J. van Hengel, Food allergens: analysis instrumentation and methods, Boca Raton: CRC Press (2011).

[2] E. Shah, J. Pongracic, Pediatrics Annals, 37 (2008) 536-541.

[3] J. Costa, I. Mafra, I. Carrapatoso, M.B.P.P. Oliveira, Journal of Agricultural and Food Chemistry, 60 (2012) 1337-1349.

[4] I. Mafra, I.M.P.L.V.O. Ferreira, M.B.P.P. Oliveira, European Food Research and Technology, 227 (2008) 649-665.

[5] J. Costa, I. Mafra, M.B.P.P. Oliveira, Food Chemistry, 133 (2012) 10621069.

[6] J. Costa, I. Mafra, T. Kuchta, M.B.P.P. Oliveira, Journal of Agricultural and FoodChemistry, 60(2012)8103-8110.

[7] J. Costa, M.B.P.P. Oliveira, I. Mafra, Novel approach based on single-tube real-time PCR to detect almond allergens in foods (submitted).

\section{Atualidade Cientifica}

\section{DOIS ELEMENTOS DA TABELA PERIÓDICA RECEBEM O SEU NOME}

Nos finais de maio de 2012, dois elementos químicos receberam as suas designações definitivas aprovadas pela IUPAC. A 30 de maio de 2012, o elemento de número atómico 114 adotou o nome de Fleróvio (símbolo químico Fl), enquanto que em 31 de maio de 2012, a IUPAC adotou para o elemento de número atómico 116 o nome de Livermório (símbolo químico Lv). O fleróvio é um elemento químico radioativo, e foi denominado em homenagem ao físico nuclear soviético Georgy Flyorov (também soletrado como Flerov), 1913-1990, o fundador do Joint Institute for Nuclear Research (JINR), em Dubna, Rússia, onde o elemento foi primeiramente descoberto em dezembro de 1998. Foram detetados até à data aproximadamente 80 decaimentos de átomos de fleróvio, 50 diretamente e 30 inferidos pelo decaimento dos elementos mais pesados livermório e ununóctio. Todos os decaimentos foram atribuídos a cinco isótopos vizinhos com números de massa na gama 285-289. O isótopo mais estável conhecido atualmente é o $289 \mathrm{FI}$, com tempo de meia vida de $2,6 \mathrm{~s}$. Estudos químicos realizados em 2007-2008 sugerem que o fleróvio é inesperadamente volátil para um elemento do grupo 14 e aparenta exibir propriedades do tipo gás nobre devido a efeitos relativísticos.

Por outro lado, o livermório é um elemento superpesado sintético colocado na tabela periódica como o elemento mais pesado do grupo 16. No entanto, de momento não é conhecido um isótopo suficientemente estável para que se possam realizar estudos que confirmem esta posição como um homólogo pesado do polónio. Foi inicialmente detetado por investigadores do JINR, em Dubna, Rússia, em julho de 2000. O nome Livermório foi adotado como reconhecimento pelo papel que o Lawrence Livermore National Laboratory, sedeado na cidade de Livermore, Califórnia, teve na colaboração que conduziu à sua descoberta. Desde a deteção inicial foram produzidos aproximadamente 35 átomos de livermório, quer diretamente, como através do decaimento de ununóctio, com quatro isótopos vizinhos de números de massa na gama 290-293. O isótopo mais estável conhecido é o $293 \mathrm{Lv}$, com um tempo de meia vida de $60 \mathrm{~ms}$. 